\title{
Formulation and Optimization of Biodegradable Periodontal Chips Containing Metronidazole and Levofloxacin
}

\author{
Pyare La ${ }^{1 *}$, A.S. William Arputha Sundar ${ }^{1}$, Yogendra Singh ${ }^{1}$. \\ ${ }^{1}$ Department of Pharmacy, Sun Rise University, Alwar, Rajasthan, India
}

\author{
*Correspondence \\ Dr. Pyare Lal, \\ Department of Pharmacy, Sun Rise University, Alwar, Rajasthan, India. \\ E-mail: bitbhaskar@gmail.com
}

Received: 04-02-2020 / Revised: 20-06-2020 / Accepted: 26-09-2020

\begin{abstract}
This research aimed to developintrapocket,biodegradablechips ofpoly(d,1-lactide-co-glycolide) (PLGA) loaded with Metronidazole (MZ) and levofloxacin (LF),for sustained release local drug delivery in periodontal pocket to treat periodontitis. Metronidazole and levofloxacin are widely employed for the treatment of periodontitis, but high oral dose and resistance development after long-term oral administration limit their use, hence local delivery is a good approach. The chips were prepared by solvent casting technique using diethyl phthalate as plasticizer. Their physical characteristics, such as drug content,surface $\mathrm{pH}$, swelling index, and folding endurance, exhibited results within limit. Further, FTIR and DSCstudies revealed stability of chips and compatibility between drugs and excipients.In vitro release in McIlvainebuffer $\mathrm{pH} 7.8$ was of sustained nature assisted by the burst effect. Design-Expert ${ }^{\circledR}$ (11.0.4) software was used to study the effect of polymer \& plasticizer on release of drugs Polymer concentrationsnegatively affected drug release and positively affected $\mathrm{T}_{90}$ (time for releasing $90 \%$ of the drug) due toaltered matrix density. In contrast, the plasticizer concentration increases membrane permeability andhence increased drug release, lowering $\mathrm{T}_{90}$. Forvarious response variables,polynomial mathematical models were generated usingmultiple regression analysis, and found to be statistically significant $(P<0.05)$. The antibacterial efficacy of films was tested on Pseudomonas spp. Bacteroides spp., indicatinggood antibacterial activity. Optimized formulations were further used for preparing optimized biodegradable, Metronidazole-Levofloxacin sustained release chip. Conclusively, the films of MZ and LF were successful tools for the management ofperiodontitis.

Keywords: Periodontitis, Metronidazole, levofloxacin,poly(d,1-lactide-co-glycolide) (PLGA), diethyl phthalate, biodegradablePeriodontal chips, Intra-pocket device.

This is an Open Access article that uses a fund-ing model which does not charge readers or their institutions for access and distributed under the terms of the Creative Commons Attribution License (http://creativecommons.org/licenses/by/4.0) and the Budapest Open Access Initiative (http://www.budapestopenaccessinitiative.org/read), which permit unrestricted use, distribution, and reproduction in any medium, provided the original work is properly credited.
\end{abstract}

\section{Introduction}

Periodontitis is a chronic bacterial infection that affects the gums and bones supporting teeth, untreated gingivitis can advance to periodontitis [1]. Gingivitis is often caused by inadequate oral hygiene. Periodontal disease can affect one tooth or many teeth. It begins when the bacteria in plaque as the disease progresses, the pockets deepen and more gum tissues and bone are destroyed. Often this destructive process has very mild symptoms. Eventually teeth become loosened and may have to be removed. Periodontal pocket provides an ideal environment for the growth of anaerobic pathogenic bacteria such as actinobacillus
Actinomycetemcomitans, Bacteroidesgingivalis, Bacteroidesmelaninogenicus subspecies intermedius, Porphyromonasgingivalis and Provetellaintermedia [2]. In combination therapy, selection of drugs should bemade such that it targets a wide range of proliferating bacteria.Metronidazole (MZ) is considered as a front-line chemotherapeuticagent and is selectively active against obligate anaerobicmicrobes residing into inflamed periodontal pockets.Also, therapeutic concentration is attained early as it haslower minimum inhibitory concentration (MIC) for the treatmentand management of periodontitis [3,4]. In addition toMZ, levofloxacin (LF) has been used due to 
its activity againstfacultative anaerobic periodontopathic bacteria. LF is an activeisomer of ofloxacin which is twice active in comparison toofloxacin and widely used for the treatment of periodontaldiseases [5].

Antimicrobial agentsMetronidazole (MZ) and levofloxacin (LF) are widely employed for treatment of periodontitis,but high oral dose and resistance development after long-term oral administration limit their use.The most common side effects of both drugs are those involving GIT (nausea, vomiting, gastric irritation), hepatic, CNS (headache, dizziness), hematological (anemia, neutropenia), and rarely respiratory [6,7].In order to achieve high local bioactivity and low systemicside effects of antibiotics in the treatment of periodontal infections, a localized controlled delivery system is desirable [8-12].

Therefore, the present study was performed to fabricate biodegradable Metronidazole-Levofloxacin sustained release chipcontaining different concentration of polymer poly (d,1-lactide-co-glycolide) (PLGA) \& plasticizer diethyl phthalate and optimization, evaluation ofsustained release MetronidazoleLevofloxacin chip for the treatment of periodontal disease.The localized administration of MZ and LF could beadvantageous for the improvement of periodontal condition inpatients in terms of targeting the pathogens in the pockets anddecreasing systemic side effects and healing time simultaneouslyleading to quick regeneration of the destructed tissues.

\section{Materials \& Methods}

\section{Materials}

Metronidazole (API), Levofloxacin(API) \&poly(DLlactide-co-glycolide)was obtained as a gift sample fromWockhardt Research Centre, Aurangabad, Maharashtra, India. Diethyl phthalate and solvents like Acetic Acid, Methylene chloride\&Chloroform were procured from R.S. Enterprises, Jaipur, India manufactured by Central Drug House (P) Ltd - CDH, New Delhi, India. All chemicals used were of analytical grade.

\section{Methods}

\section{Preformulation Studies}

Preformulation studies are useful in determining the formulation components, physicochemical properties of new drug substance, development of analytical method and compatibility of drug substance with common excipients.Physicochemical Evaluation of the drug involves its Organoleptic evaluation\&Identification of the Drug Sample by determining Solubility, Partition Coefficient, Melting Point Determination, DSC and FTIR.

Analytical methodologies include Spectrophotometric Analysis of Drug i.e. Scanning of the drug in Water\& in McIlvaine Buffer $\mathrm{pH}-7.8$ and Preparation of the Standard Curve in Water\& in McIlvaine Buffer pH-7.8. Finally compatibility studiesperformed between drug and Excepients to observe interaction.

Preparation of biodegradable sustained release Metronidazole-Levofloxacin chip

Selection of Solvent for Formulation: Drug, polymer \& plasticizer should be completely dissolved in the solvent. Therefore various solvents were used for good formulation.Four trails were done for selection of solvent i.e. Acetic Acid, Methylene chloride, Chloroform\& combination of Acetic acid and Methylene chloride (1:1). Initially all formulations were observed for their mechanical property, bioadhesion, thickness property but without incorporating drug.

Optimization of Ratio of Polymer and Concentration of Plasticizer

The optimization of the concentration of poly(d,1lactide-co-glycolide) (PLGA)was necessary for preparation of formulation and drug release parameter. Plasticizer concentration is optimized so that Mechanical strength of film obtained and bioadhesion property was achieved. Formulation was prepared using various concentration of PLGA and using Methylene Chloride as solvent and diethyl phthalate $(20 \%, 30 \% \& 40 \% \mathrm{v} / \mathrm{w}$ of that of polymer) as a plasticizer using magnetic stirrer in aclosed beaker and stirred until a clear solution was obtained. Drugs, sieved through \#300, were dispersed into polymeric solution and mixing by Magnetic stirrer until it was homogenous. The resultant polymeric mixture was cast on leveled petri plate, and dried at room temperature under an inverted funnel for $24 \mathrm{hr}$.

\section{Fabrication of Metronidazole \& Levofloxacin chips} by solvent casting method

After optimization three different quantities of poly(d,1lactide-co-glycolide) (PLGA), with three different concentration of plasticizer diethyl phthalate, was dispersed in acetic acid. 500mg each of Metronidazole and levofloxacin were dispersed into polymeric solution and the resultant polymeric mixture was cast in $0.3 \mathrm{~cm}^{2}$ frames placed on leveled petri plate of $9 \mathrm{~cm}^{2}$ diameter, and dried at room temperature under an inverted funnel for $24 \mathrm{hr}$. The films were subdivided into chip $\left(10 \times 3 \mathrm{~mm}=30 \mathrm{~mm}^{2}\right)$.

Since $28.26 \mathrm{~cm}^{2}$ area of petri plate containing $=500 \mathrm{mg}$ of drug (each)

Hence $0.3 \mathrm{~cm}^{2}$ chip/film on petri plate contained $=$ $5.3 \mathrm{mg}$ of drug (each)

All the formulation formulated and film were was cut in size $(10 \times 3 \mathrm{~mm})$ of chip, and store in air tight container. Hence each chip contained $5 \mathrm{mg}$ each of Metronidazole \& Levofloxacin with area $30 \mathrm{~mm}^{2}$. 
These formulations were evaluated for their physical characteristics, total drug contents, drug release and in

vitro antimicrobial activity.

Table 1: Composition of sustained released Film

\begin{tabular}{|l|l|l|l|l|}
\hline Formulation & $\begin{array}{l}\text { Metronidazole } \\
(\mathrm{mg})\end{array}$ & $\begin{array}{l}\text { Levofloxacin } \\
(\mathrm{mg})\end{array}$ & $\begin{array}{l}\text { poly(d,l-lactide- } \\
\text { co-glycolide) }(\mathrm{mg})\end{array}$ & $\begin{array}{l}\text { Diethyl } \\
\text { phthalate } \\
\text { Plasticizer } \\
(\mathrm{ml})\end{array}$ \\
\hline F1 & 500 & 500 & 1000 & 0.2 \\
\hline F2 & 500 & 500 & 1000 & 0.3 \\
\hline F3 & 500 & 500 & 1000 & 0.4 \\
\hline F4 & 500 & 500 & 1500 & 0.3 \\
\hline F5 & 500 & 500 & 1500 & 0.45 \\
\hline F6 & 500 & 500 & 1500 & 0.6 \\
\hline F7 & 500 & 500 & 2000 & 0.4 \\
\hline F8 & 500 & 500 & 2000 & 0.6 \\
\hline F9 & 500 & & 0.8 \\
\hline
\end{tabular}

was noted after bringing the electrode of the $\mathrm{pH}$ meter

Characterization of biodegradable Sustained Release Metronidazole-Levofloxacin Chip [13-15] Thickness \& weight variationof the Sustained Release Chip

The thickness of each periodontal film was measured using digital screw gauge (MitutoyoDigimatic micrometer) at different positions of the chips and the average was calculated.For determining weight variation chips of same size $(10 \times 3 \mathrm{~mm})$ were taken. The individual weights were determined and the average weight was calculated.

\section{Folding Enduranceand tensile strength of Sustained Release Chip}

The folding endurance or flexibility ofthe filmwas determined by repeatedly folding the film at $180^{\circ}$ angleof the plane at the same place until it breaks or folded to 300 timeswithout breaking. The number of times the films folded withoutbreaking as considered as folding endurance.

The Tensile strength of sustained release formulation was evaluated using the Instron Tensile testing Machine (Instron Model 3366). Film (Chip) in special dimensions and free from air bubbles or physical physical imperfections were held between twp clamps position at distance of $65 \mathrm{~mm}$. During measurentment, the film were pulled by the top clamp at a rate of $50 \mathrm{~mm} / \mathrm{min}$, and the force and elongation were measured in triplicate when the film broken.

\section{Surface $\mathbf{p H}$ and Swelling Index}

The surface $\mathrm{pH}$ of the films was determined in order to check out the possible side effects due to change in $\mathrm{pH}$ in vivo, since an acidic or alkaline $\mathrm{pH}$ may cause irritation to the periodontal mucosa. The film to be tested was placed in a Petri dish and was moistened with $0.5 \mathrm{ml}$ of distilled water and kept for $1 \mathrm{~h}$. The $\mathrm{pH}$ in contact with the surface of the formulation and allowing equilibrating for 1 minute.

The swelling index was calculated to study the hydration characteristics of the films. After drying in an oven, the $1 \times 1 \mathrm{~cm}$ films were weighed (W1) and allowed to swell in petri dish $(3.5 \mathrm{~cm}$ diameter) containing $5 \mathrm{ml}$ Mcllvaine buffer $(\mathrm{pH}$ 6.6). At predefined intervals up to $24 \mathrm{~h}$, the swollen films were reweighed (W2) after drying the excess of water from the surface of films using filter paper (19). The swelling index of each system was calculated using the following equation:

$\%$ Swelling index $=\frac{W 2-W 1}{W 1} \mathrm{x} 100 \ldots \ldots \ldots \ldots . .$. Eq.1

Estimation of Total Drug Content and Drug Content Uniformity of Chip:

For determination of total drug content and uniformity of drug content, 4 chips $(10 \times 3 \mathrm{~mm})$ from each formulation were weighed individually and placed in a100 ml volumetric flask containing mixture (1:1) of Acetic acid and Methylene Chlorideto dissolve the chip and the volume was made up in Mcllvaine buffer $(\mathrm{pH}$ 7.8). The resultant solution was filtered through a G-2 glass filter. An aliquot of the filtrate was suitably diluted and analyzed for Metronidazole contents at $319.20 \mathrm{~nm}$ and for Levofloxacin contents at $289 \mathrm{~nm}$ in UV-Visible Spectrophotometer (UV-1800 Shimadzu).

$\%$ Drug Content $=$ Sample Absorbance/ Standard Absorbance x 100..............Eq.2

\section{In vitro Release study}

The chips of Metronidazole and Levofloxacin were placed in $10 \mathrm{~mL}$ vials. To these, $5 \mathrm{~mL}$ of McIlvaine buffer of $\mathrm{pH} 7.8$ was transferred and tightly closed. The temperature of the dissolution medium was maintained at $37^{\circ} \mathrm{C}$ by placing the vial in anincubator. Every $24 \mathrm{hr}$ the dissolution medium was taken out and replaced with fresh medium. The amount of 
drug(Metronidazole) released into the medium was determined by measuring the absorbance at $320 \mathrm{~nm}$ using a Shimadzu- 1800UV PC spectrophotometer after suitable dilution and the amount of drug(Levofloxacin) released into the medium was determined by measuring the absorbance at $289 \mathrm{~nm}$ using a Shimadzu- 1800UV PC spectrophotometer after suitable dilution. The in-vitrostudy was done with three replicates for 6 days. The formulationswhich had shown good release profile was chosen for the in- vitro microbial study. Cumulative drug release was calculated on the basis of mean amount of DOM present in the respective tablet by the formula:

Amount released $(\mathrm{mg})=\frac{\text { Concentration } \times \text { Bath volume } \times \text { Dilution factor }}{1000} \ldots \ldots . .$. Eq.3

Percent drug release $(\mathrm{PDR})=\frac{\text { Amount released }}{\text { Drug content }} \times 100$

\section{Determination of Residual Drug Content in Chip}

Residual drug content of chip was determined by dissolving residual chip in $0.5 \mathrm{ml}$ Methylene Chloride in $100 \mathrm{~mL}$ volumetric flack volume was make up by McIlvaine buffer $\mathrm{pH}-7.8$ and the resultant solution was filtered through a G-2 glass filter. An aliquot of the filtrate was suitably diluted and analyzed for Metronidazole and Levofloxacin contents at 320nm and 289nm in UV-Visible Spectrophotometer (UV1800 Shimadzu).

\section{Mass Balance Studies}

The mass balance studies are conducted as all the drug in the chip was not released within the period of static dissolution study. Following the in-vitro release studies (static) the test Chip were analysed to determine the remaining drug content in the chip. After drying each chip the residual drug content could be analyzed by dissolving in $0.5 \mathrm{ml}$ Methylene chloride and diluted suitably with McIlvaine buffer $\mathrm{pH}-7.8$. The resultant solution was filtered through a G-2 glass filter. An aliquot of the filtrate was suitably diluted and analyzed for Metronidazole contents at 320nm and Levofloxacin at $289 \mathrm{~nm}$ in UV- Visible Spectrophotometer (UV-1800 Shimadzu) respectively. The amount of drug released into the dissolution medium plus residual drug content in the films were accounted and compared for actual drug content.

\section{FTIR Spectroscopy}

The Spectra were recorded from $4000-600 \mathrm{~cm}^{-1}$, using FTIR spectrophotometer (FTIR 8400s, Shimadzu) on samples prepared as $\mathrm{KBr}$ disks (1 $\mathrm{mg}$ of sample and 50 $\mathrm{mg}$ of $\mathrm{KBr}$ ) and compared with the only drug without formation of complexes identified on the basis of appearance of a new peaks and disappearance of some identified peaks from the spectrum of pure drug.

\subsection{Thermal analysis studies}

Thermal analysis studies were done by Thermo gravimetry analysis (TGA). Formulation was examined by means of Thermo gravimetry analyzer. These experiments were performed on a DTG-60 TGA(Shimadzu, Japan) The samples was placed in an aluminum pans before heating under nitrogen environment at a scanning rate of $10^{\circ} \mathrm{C} \mathrm{min}^{-1}$, from $25^{\circ} \mathrm{C}$ to $400^{\circ} \mathrm{C}$.

\section{Result \& Discussion}

Organoleptic properties of drug indicated that drugs were almost white in color and odourless. The melting point of Metronidazole and Levofloxacin was recorded at $161.1^{\circ} \mathrm{C}$ and $215.3^{\circ} \mathrm{C}$ respectively. The partition coefficient value $\mathrm{P}$ was found to be $2.54 \pm 0.125 \&$ $0.02 \pm 0.001$ respectively.

The solubility of Metronidazole in different media viz. in water, ethanol, acetic acid, Dimethyl Chloride and McIlvainebuffer $\mathrm{pH} 7.8$ was found to be $9.5 \mathrm{mg} / \mathrm{ml}$, $5 \mathrm{mg} / \mathrm{ml}, \quad 6.5 \mathrm{mg} / \mathrm{ml}, \quad 4.12 \mathrm{mg} / \mathrm{mland} \quad 2 \mathrm{mg} / \mathrm{ml}$ respectively.The solubility of Levofloxacin in different media viz. in water, ethanol, acetic acid, Dimethyl Chloride and McIlvainebuffer $\mathrm{pH} 7.8$ was found to be $25 \mathrm{mg} / \mathrm{ml}, 1 \mathrm{mg} / \mathrm{ml}, 92 \mathrm{mg} / \mathrm{ml}, 101 \mathrm{mg} / \mathrm{mland} 98 \mathrm{mg} / \mathrm{ml}$ respectively.

Drug and drug polymer interaction studies were successfully carried out. Mixtures were found to be stable under selected storage conditions for one month, as there was no change in their physical characteristics. Hence, it was observed that the selected polymer and plasticizer were compatible with both drugs.

Solvent selection was made and acetic acid selected as solvent for the preparation of Metronidazole and Levofloxacinperiodontal chips which showed good formulation parameter like thickness, hardness, film appearance etc for the preparation of periodontal chips. Optimization of Polymer amount and Plasticizer'sconcentration is done by preparing placebo trials of chips with or without drug. It was observed that between $1000-2000 \mathrm{mg}$ of polymer, as the amount increases the release rate controlled and after this there is only increase in thickness of the film/chip; diethylphthalate $(20 \%, 30 \% \& 40 \%$ v/w of that of polymer) selected as plasticizer.

Nine formulations of polymer PLGA[85:15] with plasticizer in optimized ratio were prepared of Metronidazole-Levofloxacin by solvent casting method 
using factorial design. Allformulations were characterized for drug content, phase solubility studies, in-vitro dissolution studies, Fourier-transform infrared (FTIR) spectroscopy, and in-vitro antimicrobialactivity.
Thickness\& weight variation of the Sustained Release Chip

All the Chips were found in uniformity for weight, as well as the thickness of all chips were below $0.5 \mathrm{~mm}$ which was also good for inserting dental pockets. The data is shown in Table2.

Table 2: Physical characteristics of drug loaded chip containing PLGA [85:15]

\begin{tabular}{|l|l|l|}
\hline Batch/Chip Code & Weight & Thickness \\
\hline MLC-1 & $7.7 \pm 0.14$ & $0.287 \pm 0.03$ \\
\hline MLC-2 & $7.9 \pm 0.12$ & $0.271 \pm 0.01$ \\
\hline MLC-3 & $7.6 \pm 0.14$ & $0.276 \pm 0.02$ \\
\hline MLC-4 & $10.6 \pm 0.12$ & $0.354 \pm 0.01$ \\
\hline MLC-5 & $10.1 \pm 0.14$ & $0.325 \pm 0.01$ \\
\hline MLC-6 & $10.5 \pm 0.16$ & $0.34 \pm 0.02$ \\
\hline MLC-7 & $11.2 \pm 0.1$ & $0.458 \pm 0.02$ \\
\hline MLC-8 & $11.7 \pm 0.12$ & $0.444 \pm 0.01$ \\
\hline MLC-9 & $11 \pm 0.12$ & $0.462 \pm 0.02$ \\
\hline
\end{tabular}

concentration but decreases with addition of the drug.

Folding Enduranceand tensile strength of Sustained It was also found that the tensile strength increases with increase in concentration of polymer.The data is Release Chip

Folding endurance \& Tensile strength of all shown in Table3. Fig. 2 showingeffect of PLGA formulations was evaluated and it was observed that both the parameters increased by increasing polymer

[85:15] on tensile strength of chip.

Table 3: Folding endurance \& Tensile strength of chips containing PLGA [85:15]

\begin{tabular}{|l|l|l|}
\hline Chip Code & Folding endurance $($ Mean \pm SD $)$ & Tensile strength $($ Mean \pm SD) Mp \\
\hline MLC-1 & $294 \pm 0.25$ & $0.094 \pm 0.003$ \\
\hline MLC-2 & $299 \pm 0.12$ & $0.09 \pm 0.001$ \\
\hline MLC-3 & $309 \pm 0.23$ & $0.092 \pm 0.002$ \\
\hline MLC-4 & $297 \pm 0.56$ & $0.198 \pm 0.021$ \\
\hline MLC-5 & $305 \pm 0.78$ & $0.182 \pm 0.015$ \\
\hline MLC-6 & $317 \pm 0.28$ & $0.215 \pm 0.023$ \\
\hline MLC-7 & $296 \pm 0.45$ & $0.312 \pm 0.057$ \\
\hline MLC- 8 & $304 \pm 0.12$ & $0.345 \pm 0.065$ \\
\hline MLC-9 & $311 \pm 0.45$ & $0.321 \pm 0.031$ \\
\hline
\end{tabular}

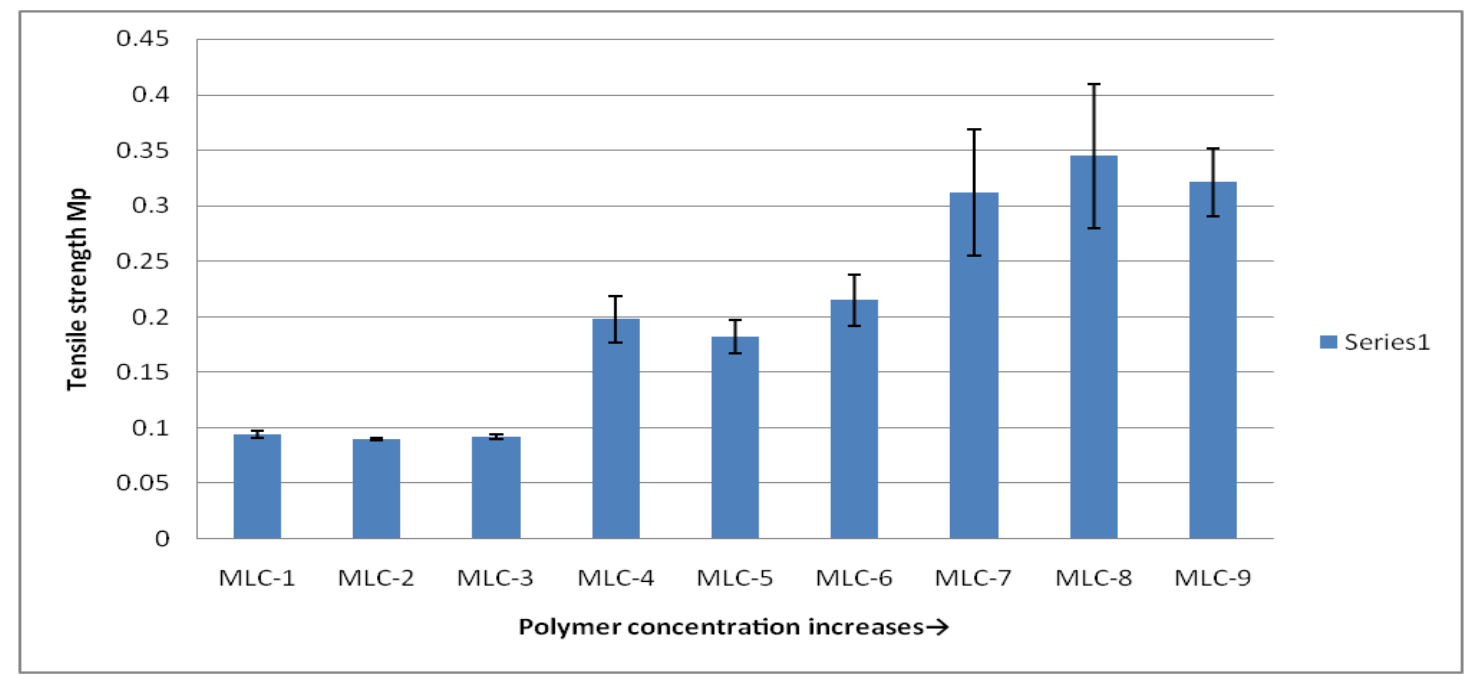

Fig. 2: Effect of PLGA [85:15] on tensile strength

Lal et al www.apinh.com 


\section{Surface pH and Swelling Index}

Surface $\mathrm{pH} \&$ Swelling Index all the formulations were determined. Surface $\mathrm{pH}$ of all the formulationswere found to have $\mathrm{pH}$ between $6-7$ may not cause any
irritation.Swelling index of all formulations containing PLGA [85:15] was calculated. It was observed that as the concentration of polymer increased, swelling index also increased.The data is shown in Table4.

Table 4: Surface pH \& Swelling Index ofchips containing PLGA [85:15]

\begin{tabular}{|l|l|l|}
\hline Batch/Chip Code & Surface $\mathrm{pH}$ & Swelling Index (\%) (Mean \pm SD) \\
\hline MLC-1 & $6.56 \pm 0.07$ & $24.5 \pm 0.6$ \\
\hline MLC-2 & $6.59 \pm 0.05$ & $25.9 \pm 0.4$ \\
\hline MLC-3 & $6.72 \pm 0.03$ & $27 \pm 0.7$ \\
\hline MLC-4 & $6.65 \pm 0.08$ & $31.4 \pm 0.8$ \\
\hline MLC-5 & $6.59 \pm 0.09$ & $32.6 \pm 0.7$ \\
\hline MLC-6 & $6.5 \pm 0.07$ & $33.3 \pm 0.5$ \\
\hline MLC-7 & $6.52 \pm 0.02$ & $35.4 \pm 0.2$ \\
\hline MLC-8 & $6.58 \pm 0.07$ & $35.8 \pm 0.4$ \\
\hline MLC-9 & $6.63 \pm 0.09$ & $38.6 \pm 0.4$ \\
\hline
\end{tabular}

Estimation of Total Drug Content and Drug Content Uniformity of Chip

The percent drug content of the chips was found between $85.53 \%-93.40 \%$ of Levofloxacin, containing PLGA [85:15]. The percent drug content of the chips was found between $87.11 \%-94.65 \%$ of Metronidazole,

Table 5: Total drug content and drug content uniformity- Metronidazole

\begin{tabular}{|l|l|l|l|l|l|}
\hline $\begin{array}{l}\text { Chip } \\
\text { code }\end{array}$ & Absorbance $(\mathrm{nm})$ & $\begin{array}{l}\text { Total drug } \\
\text { contents }(\mu \mathrm{g})\end{array}$ & $\begin{array}{l}\text { Theoretical drug } \\
\text { content }(\mu \mathrm{g})\end{array}$ & $\begin{array}{l}\% \text { Drug Content* } \\
(\text { Mean } \pm \text { SD })\end{array}$ \\
\hline MLC-1 & 0.286 & 4533.3 & 5300 & 85.53 \\
\hline MLC-2 & 0.299 & 4750 & 5300 & 89.62 \\
\hline MLC-3 & 0.294 & 4666.7 & 5300 & 88.05 \\
\hline MLC-4 & 0.304 & 4833.3 & 5300 & 91.19 \\
\hline MLC-5 & 0.307 & 4883.3 & 5300 & 92.14 \\
\hline MLC-6 & 0.311 & 4950 & 5300 & 93.4 \\
\hline MLC-7 & 0.296 & 4700 & 5300 & 88.68 \\
\hline MLC-8 & 0.301 & 4783.3 & 5300 & 90.25 \\
\hline MLC-9 & 0.302 & 4800 & 5300 & 90.57 \\
\hline
\end{tabular}

Table 6: Total drug content and drug content uniformity- Levofloxacin

\begin{tabular}{|l|l|l|l|l|}
\hline Chip code & $\begin{array}{l}\text { Absorbance } \\
(\mathrm{nm})\end{array}$ & $\begin{array}{l}\text { Total drug } \\
\text { contents }(\mu \mathrm{g})\end{array}$ & $\begin{array}{l}\text { Theoretical drug } \\
\text { content }(\mu \mathrm{g})\end{array}$ & $\begin{array}{l}\% \text { Drug } \\
(\text { Mean } \pm \text { SD })\end{array}$ \\
\hline MLC-1 & 0.291 & 4616.7 & 5300 & 87.11 \\
\hline MLC-2 & 0.295 & 4683.3 & 5300 & 88.36 \\
\hline MLC-3 & 0.299 & 4750 & 5300 & 89.62 \\
\hline MLC-4 & 0.309 & 4916.7 & 5300 & 92.77 \\
\hline MLC-5 & 0.311 & 4950 & 5300 & 93.4 \\
\hline MLC-6 & 0.315 & 5016.7 & 5300 & 94.65 \\
\hline MLC-7 & 0.301 & 4783.3 & 5300 & 90.25 \\
\hline MLC-8 & 0.305 & 4850 & 5300 & 91.51 \\
\hline MLC-9 & 0.307 & 4883.3 & 5300 & 92.14 \\
\hline
\end{tabular}

In vitro Release study

In-Vitro Release Studies was assessed and it was observed that initially drug release wasat burst effect but later on sustained effect and up to 5 days drug release was in the range of MIC for various Microbes containing PLGA [85:15]. Drug content of all the formulations was found to be within the limits. It was observed that as the amount of polymer increases drug content also increases proportionally. The data is shown in Table $5 \& 6$.

\section{Lal et al




\begin{tabular}{|c|c|c|c|c|c|c|c|c|c|}
\hline \multicolumn{10}{|c|}{ Table 7: Dissolution Time-Profile of Metronidazole of Chip Containing PLGA [85:15] } \\
\hline \multirow{3}{*}{$\begin{array}{l}\text { Time } \\
\text { (days) }\end{array}$} & \multicolumn{9}{|c|}{$\%$ Cumulative drug release*(Mean \pm SD $)$} \\
\hline & \multicolumn{9}{|c|}{ Formulation Code } \\
\hline & MLC-1 & MLC-2 & MLC-3 & MLC-4 & MLC-5 & MLC-6 & MLC-7 & MLC-8 & MLC-9 \\
\hline 1 & $\begin{array}{l}63.51 \quad \pm \\
0.42\end{array}$ & $\begin{array}{l}64.61 \quad \pm \\
0.19\end{array}$ & $\begin{array}{l}64.61 \quad \pm \\
0.34\end{array}$ & $\begin{array}{l}65.55 \quad \pm \\
0.13\end{array}$ & $\begin{array}{l}66.66 \quad \pm \\
0.28\end{array}$ & $\begin{array}{l}67.76 \pm \\
0.91\end{array}$ & $\begin{array}{l}63.04 \quad \pm \\
0.91\end{array}$ & $\begin{array}{l}63.83 \quad \pm \\
0.28\end{array}$ & $\begin{array}{l}64.61 \quad \pm \\
0.71\end{array}$ \\
\hline 2 & $\begin{array}{l}72.63 \\
0.91\end{array}$ & $\begin{array}{l}73.73 \quad \pm \\
0.11\end{array}$ & $\begin{array}{ll}75.3 & \pm \\
0.28 & \end{array}$ & $\begin{array}{l}79.08 \quad \pm \\
0.11\end{array}$ & $\begin{array}{ll}80.81 \quad \pm \\
0.11\end{array}$ & $\begin{array}{ll}81.91 \quad \pm \\
0.65\end{array}$ & $\begin{array}{ll}75.77 \quad \pm \\
0.42 & \end{array}$ & $\begin{array}{ll}77.03 \quad \pm \\
0.24\end{array}$ & $\begin{array}{ll}78.13 \quad \pm \\
0.42\end{array}$ \\
\hline 3 & $\begin{array}{l}75.42 \\
0.72\end{array}$ & $\begin{array}{l}76.56 \quad \pm \\
0.65\end{array}$ & $\begin{array}{ll}79.71 \quad \pm \\
0.13\end{array}$ & $\begin{array}{l}84.42 \quad \pm \\
0.21\end{array}$ & $\begin{array}{l}86.12 \quad \pm \\
0.91\end{array}$ & $\begin{array}{ll}88.35 \quad \pm \\
0.42\end{array}$ & $\begin{array}{ll}80.49 \quad \pm \\
0.19\end{array}$ & $\begin{array}{ll}81.59 \quad \pm \\
0.13\end{array}$ & $\begin{array}{ll}83.32 \quad \pm \\
0.65\end{array}$ \\
\hline 4 & $\begin{array}{l}77.03 \\
0.11\end{array}$ & $\begin{array}{l}78.13 \quad \pm \\
0.13\end{array}$ & $\begin{array}{l}81.22 \quad \pm \\
0.91\end{array}$ & $\begin{array}{l}86.42 \quad \pm \\
0.42\end{array}$ & $\begin{array}{l}88.2 \quad \pm \\
0.65\end{array}$ & $\begin{array}{l}91.02 \pm \\
0.71\end{array}$ & $\begin{array}{l}82.06 \quad \pm \\
0.71\end{array}$ & $\begin{array}{ll}83.01 \quad \pm \\
0.24\end{array}$ & $\begin{array}{ll}85.05 \quad \pm \\
0.28\end{array}$ \\
\hline 5 & $\begin{array}{l}77.19 \\
0.91\end{array}$ & $\begin{array}{l}78.29 \quad \pm \\
0.65\end{array}$ & $\begin{array}{l}81.44 \quad \pm \\
0.17\end{array}$ & $\begin{array}{l}86.62 \quad \pm \\
0.71\end{array}$ & $\begin{array}{l}88.35 \quad \pm \\
0.11\end{array}$ & $\begin{array}{l}91.18 \quad \pm \\
0.11\end{array}$ & $\begin{array}{l}82.22 \quad \pm \\
0.22\end{array}$ & $\begin{array}{l}83.16 \quad \pm \\
0.42\end{array}$ & $\begin{array}{ll}85.21 \quad \pm \\
0.17\end{array}$ \\
\hline
\end{tabular}

Drug content (theoretical) $-5.3 \mathrm{mg}$

Static dissolution conditions are: Temperature $=37^{\circ} \mathrm{C}$

Medium = McIlvaine buffer, $\mathrm{pH} 7.8(5 \mathrm{ml})$ Dilution factor $=100 \mathrm{ml}$

Table 8: Dissolution Time-Profile of Levofloxacin of Chip Containing PLGA [85:15]

\begin{tabular}{|c|c|c|c|c|c|c|c|c|c|}
\hline \multirow{3}{*}{$\begin{array}{l}\text { Time } \\
\text { (days) }\end{array}$} & \multicolumn{9}{|c|}{$\%$ Cumulative drug release $*($ Mean \pm SD $)$} \\
\hline & \multicolumn{9}{|c|}{ Formulation Code } \\
\hline & MLC-1 & MLC-2 & MLC-3 & MLC-4 & MLC-5 & MLC-6 & MLC-7 & MLC-8 & MLC-9 \\
\hline 1 & $\begin{array}{l}67.29 \pm \\
0.48\end{array}$ & $\begin{array}{l}68.39 \pm \\
0.51\end{array}$ & $\begin{array}{l}68.39 \pm \\
0.48\end{array}$ & $\begin{array}{l}69.33 \quad \pm \\
0.82\end{array}$ & $\begin{array}{l}70.44 \quad \pm \\
0.48\end{array}$ & $\begin{array}{l}71.54 \quad \pm \\
0.19\end{array}$ & $\begin{array}{l}66.82 \quad \pm \\
0.48\end{array}$ & $\begin{array}{l}67.61 \quad \pm \\
0.24\end{array}$ & $\begin{array}{ll}68.39 & \pm \\
0.24 & \end{array}$ \\
\hline 2 & $\begin{array}{l}76.41 \pm \\
0.71\end{array}$ & $\begin{array}{l}77.51 \quad \pm \\
0.24\end{array}$ & $\begin{array}{l}79.08 \pm \\
0.19\end{array}$ & $\begin{array}{l}82.86 \pm \\
0.24\end{array}$ & $\begin{array}{ll}84.59 & \pm \\
0.92 & \end{array}$ & $\begin{array}{l}85.69 \pm \\
0.92\end{array}$ & $\begin{array}{l}79.55 \quad \pm \\
0.78\end{array}$ & $\begin{array}{l}80.81 \quad \pm \\
0.92\end{array}$ & $\begin{array}{l}81.91 \quad \pm \\
0.24\end{array}$ \\
\hline 3 & $\begin{array}{l}79.2 \\
0.12 \\
\end{array}$ & $\begin{array}{l}80.34 \\
0.15 \\
\end{array}$ & $\begin{array}{ll}83.49 & \pm \\
0.15 & \end{array}$ & $\begin{array}{ll}88.20 \quad \pm \\
0.92\end{array}$ & $\begin{array}{l}89.9 \\
0.25 \\
\end{array}$ & $\begin{array}{l}92.13 \pm \\
0.24\end{array}$ & $\begin{array}{ll}84.27 \quad \pm \\
0.12\end{array}$ & $\begin{array}{ll}85.37 \quad \pm \\
0.19\end{array}$ & $\begin{array}{l}87.10 \pm \\
0.12\end{array}$ \\
\hline 4 & $\begin{array}{l}80.81 \\
0.92\end{array}$ & $\begin{array}{l}81.91 \\
0.71\end{array}$ & $\begin{array}{l}85.0 \\
0.19\end{array}$ & $\begin{array}{l}90.2 \\
0.71\end{array}$ & $\begin{array}{l}91.98 \pm \\
0.24\end{array}$ & $\begin{array}{l}94.8 \\
0.48\end{array}$ & $\begin{array}{l}85.84 \pm \\
0.15\end{array}$ & $\begin{array}{ll}86.79 & \pm \\
0.15 & \end{array}$ & $\begin{array}{ll}88.83 \quad \pm \\
0.19\end{array}$ \\
\hline 5 & $\begin{array}{l}80.97 \\
0.57\end{array}$ & $\begin{array}{l}82.07 \\
0.12\end{array}$ & $\begin{array}{l}85.22 \quad \pm \\
0.48\end{array}$ & $\begin{array}{l}90.40 \quad \pm \\
0.82\end{array}$ & $\begin{array}{l}92.13 \pm \\
0.92\end{array}$ & $\begin{array}{l}94.96 \pm \\
0.71\end{array}$ & $\begin{array}{l}86.00 \pm \\
0.71\end{array}$ & $\begin{array}{ll}86.94 \quad \pm \\
0.71\end{array}$ & $\begin{array}{l}88.99 \quad \pm \\
0.78\end{array}$ \\
\hline
\end{tabular}

Drug content (theoretical) $-5.3 \mathrm{mg}$

Static dissolution conditions are: Temperature $=37^{\circ} \mathrm{C}$

Medium = McIlvaine buffer, $\mathrm{pH} 7.8(5 \mathrm{ml})$ Dilution factor $=100 \mathrm{ml}$

Determination of Residual Drug Content in Chip

Residual drug content for all formulation were determined and show that there was not any drug polymer interaction and there was not formulation of any strong bond between polymer and drug. The data is shown in Table9 \& 10.

Mass Balance Studies

The mass balance studies were attempted and the total amount of drug loaded in the films was accounted for in vitro evaluation. In all the cases the amount of drug released (in static dissolution studies) plus the recovered residual drug content did not deviate by more than $3 \%$. This also concludes that drug is in free form rather than chemically or physically bound to polymer. Formulation MLC-6 showed maximum release of Mentronidazole\& Levofloxacin with minimal residual concentration and minimum mass balance. The data is shown in Table $9 \& 10$.Fig $3 \& 4$ showing \% drug Release, \% Residual \& \% Mass Balance in PLGA [85:15] chipsof Metronidazole \&Levofloxacin respectively.

Table 9: Mass balance studies of Metronidazole of chips containing PLGA [85:15]

\begin{tabular}{|l|l|l|l|l|}
\hline Chip code & $\begin{array}{l}\% \text { drug Release } \\
\text { (Metronidazole) }\end{array}$ & $\begin{array}{l}\% \text { Residual drug } \\
\text { (Metronidazole) }\end{array}$ & total drug content & Mass Balance \\
\hline MLC-1 & 77.19 & 20.82 & 98.01 & 1.99 \\
\hline MLC-2 & 21.75 & 99.04 & 0.96 \\
\hline MLC-3 & 18.29 & 11.57 & 99.01 & 0.99 \\
\hline MLC-4 & 81.44 & 11.65 & 98.50 & 1.50 \\
\hline MLC-5 & 88.62 & 99.00 & 1.00 \\
\hline
\end{tabular}

Lal et al

ASIAN PACIFIC JOURNAL OF NURSING AND HEALTH SCIENCES, 2020; 3(2):25-37

www.apjnh.com 


\begin{tabular}{|l|l|l|l|l|}
\hline MLC-6 & 91.18 & 08.17 & 99.35 & 0.65 \\
\hline MLC-7 & 82.22 & 16.75 & 98.97 & 1.03 \\
\hline MLC-8 & 83.16 & 15.54 & 98.70 & 1.30 \\
\hline MLC-9 & 85.21 & 12.82 & 98.03 & 1.97 \\
\hline
\end{tabular}

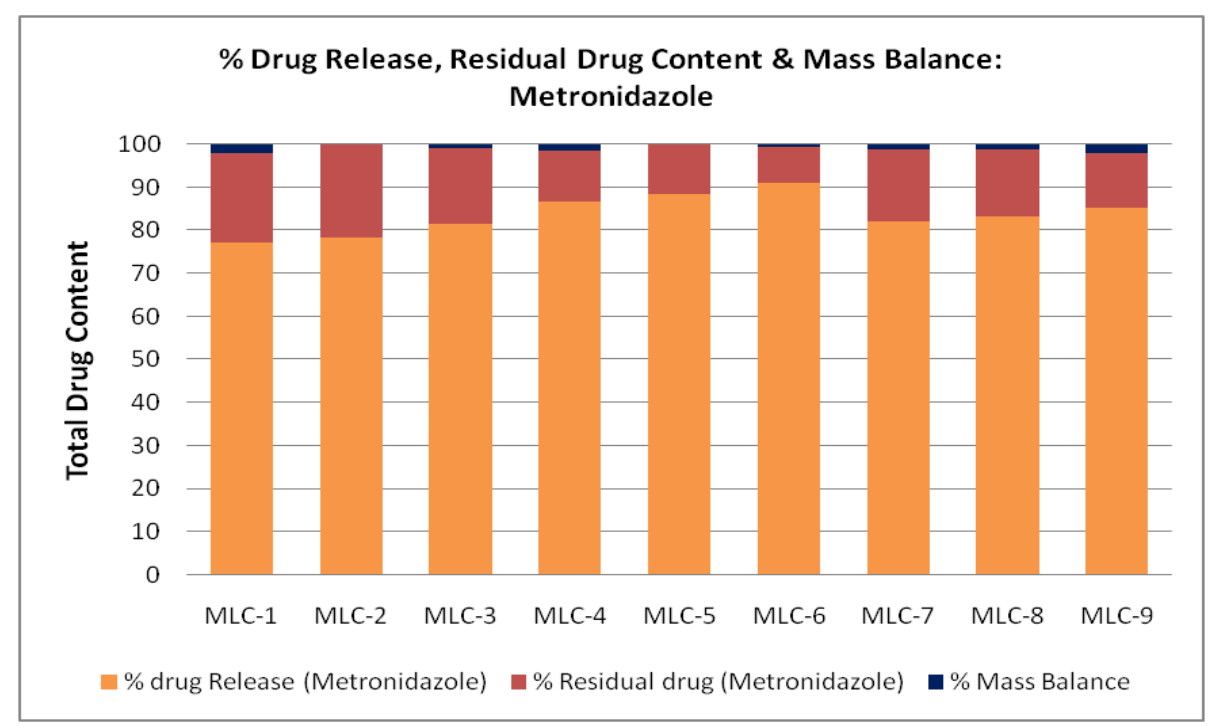

Fig 3: \% drug Release, \% Residual \& \% Mass Balance of Metronidazole in PLGA [85:15] chips Table 10: Mass balance studies of Levofloxacin of chips containing PLGA [85:15]

\begin{tabular}{|l|l|l|l|l|}
\hline Chip code & $\begin{array}{l}\% \text { drug Release } \\
\text { (Levofloxacin) }\end{array}$ & $\begin{array}{l}\% \text { Residual drug } \\
\text { (Levofloxacin) }\end{array}$ & $\%$ total drug content & \% Mass Balance \\
\hline MLC-1 & 80.97 & 18.25 & 99.22 & 0.78 \\
\hline MLC-2 & 82.07 & 15.81 & 97.88 & 2.12 \\
\hline MLC-3 & 85.22 & 13.46 & 98.68 & 1.32 \\
\hline MLC-4 & 90.40 & 8.27 & 98.67 & 1.33 \\
\hline MLC-5 & 92.13 & 6.85 & 98.98 & 1.02 \\
\hline MLC-6 & 94.96 & 4.15 & 99.11 & 0.89 \\
\hline MLC-7 & 86.00 & 12.18 & 98.18 & 1.82 \\
\hline MLC-8 & 86.94 & 11.17 & 98.11 & 1.89 \\
\hline MLC-9 & 88.99 & 10.00 & 98.99 & 1.01 \\
\hline
\end{tabular}

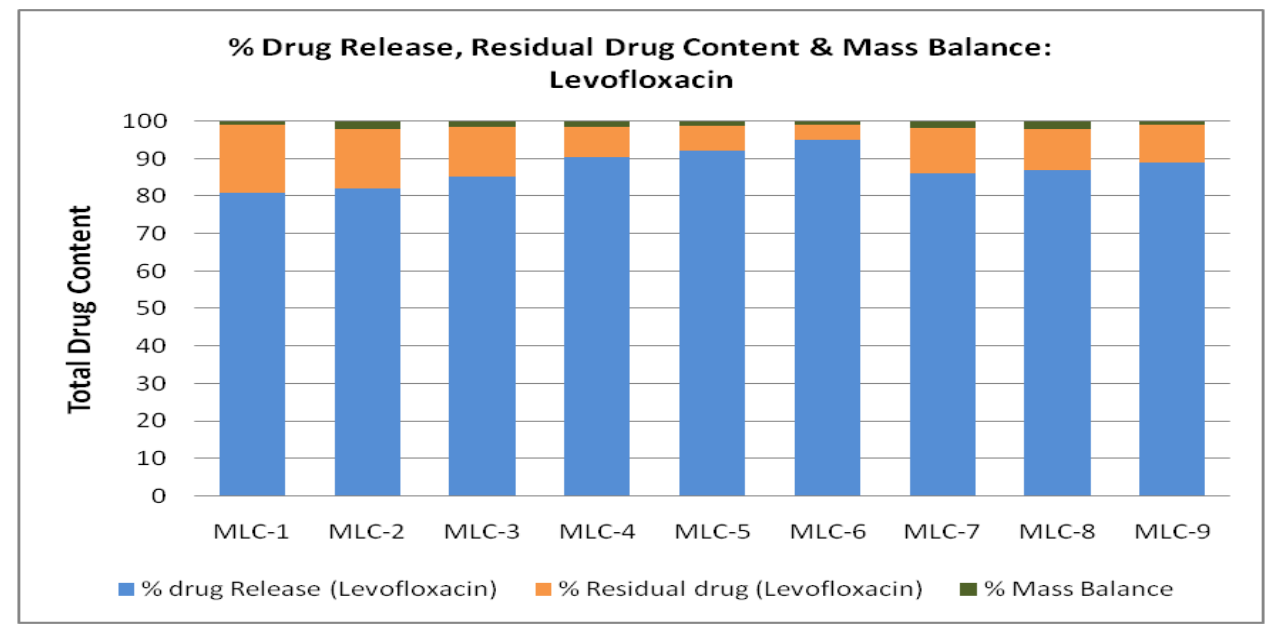

Fig 4: \% drug Release, \% Residual \& \% Mass Balance of Levofloxacin in PLGA [85:15] chips 


\section{FTIR Spectroscopy}

FTIR spectrometric analysis was done for all the prepared formulations and result showed that there was not appearance of any new peak(s) and disappearance of peak(s) from formulation containing different concentration of polymer.

\section{Thermal analysis studies}

A thermal analysis study was done by means of Thermo gravimetry analyzer. TGA show that there was not weight loss due to increase temperature up to $100^{\circ} \mathrm{C}$., so in formulation the amount of solvent was evaporated after 48 hours.

\section{Optimization of drug loaded Film Formulation} Using $3^{2}$ Full Factorial Designs

To know the actual amount and effect of two independent variables on three different quantitative levels i.e. concentration of Poly $\left(\mathrm{X}_{1}\right)$ and concentration of diethyl phthalate $\left(\mathrm{X}_{2}\right)$ on responses $3^{2}$ full factorial design was used. In this design, concentrations of Poly and diethyl phthalate were used as independent variables; while folding endurance, swelling index and $\%$ drug release were selected as response variables. The detailed layout of factorial batches is shown in Table 11.

The equations containing independent variables and response variables were obtained by statistical evaluation. Design Expert 11.0.4 was used to perform multiple linear regressions to determine the control factors which have major impact on the responses. Polynomial equation for $3^{2}$ full factorial design:

$\mathrm{Y}=\mathrm{b}_{0}+\mathrm{b}_{1} \mathrm{X}_{1}+\mathrm{b}_{2} \mathrm{X}_{2}+\mathrm{b}_{11} \mathrm{X}_{1} \mathrm{X}_{1}+\mathrm{b}_{22} \mathrm{X}_{2} \mathrm{X}_{2}+\mathrm{b}_{12} \mathrm{X}_{1} \mathrm{X}_{2}$ was used.

In this equation, $\mathrm{Y}$ is the dependent variable, $\mathrm{b} 0$ is the arithmetic mean response of the 9 factorial batches and bi is the estimated coefficient for the independent factor $\mathrm{Xi}$. The terms of full model having nonsignificant $\mathrm{p}$ value $(\mathrm{p}>0.05)$ have negligible contribution hence they were neglected.

Table 11: $3^{2}$ Full Factorial Design Layout (MLC PLGA 85:15)

\begin{tabular}{|c|c|c|c|c|c|}
\hline \multirow[t]{2}{*}{ Batch Codes } & \multicolumn{2}{|c|}{$\begin{array}{l}\text { Variable Levels in Coded } \\
\text { Form }\end{array}$} & \multirow{2}{*}{$\begin{array}{l}\text { folding endurance } \\
(\mathrm{Mp})\end{array}$} & \multirow{2}{*}{$\begin{array}{ll}\% & \text { CPR } \\
\text { Metronidazole } & \\
\text { Disso }(\%) & \end{array}$} & \multirow{2}{*}{$\begin{array}{l}\% \text { CPR } \\
\text { Levofloxacin } \\
\text { Disso }(\%)\end{array}$} \\
\hline & $\mathrm{X}_{1}$ & $\mathrm{X}_{2}$ & & & \\
\hline MLC-1 & -1 & -1 & 294 & 77.19 & 80.97 \\
\hline MLC-2 & -1 & 0 & 299 & 78.29 & 82.07 \\
\hline MLC-3 & -1 & 1 & 309 & 81.44 & 85.22 \\
\hline MLC-4 & 0 & -1 & 297 & 86.62 & 90.4 \\
\hline MLC-5 & 0 & 0 & 305 & 88.35 & 92.13 \\
\hline MLC-6 & 0 & 1 & 317 & 91.18 & 94.96 \\
\hline MLC-7 & 1 & -1 & 296 & 82.22 & 86 \\
\hline MLC-8 & 1 & 0 & 304 & 83.16 & 86.94 \\
\hline MLC-9 & 1 & 1 & 311 & 85.21 & 88.99 \\
\hline OPT & 0.936 & 1.000 & 312.86 & 86.22 & 90.00 \\
\hline \multirow[t]{2}{*}{ Coded values } & \multicolumn{2}{|c|}{ Actual values } & & & \\
\hline & $\mathrm{X}_{1}(\mathrm{mg})$ & $\mathrm{X}_{2}\left(\%\right.$ of $\left.\mathrm{X}_{1}\right)$ & & & \\
\hline-1 & 1000 & 20 & & & \\
\hline 0 & 1500 & 30 & & & \\
\hline 1 & 2000 & 40 & & & \\
\hline
\end{tabular}

$\mathrm{X}_{1}$ indicates amount of PLGA [85:15] (mg); $\mathrm{X}_{2}$, quantity of Diethyl Phthalate (mL); PCP used as checks point and optimized batch. $(n=6)$
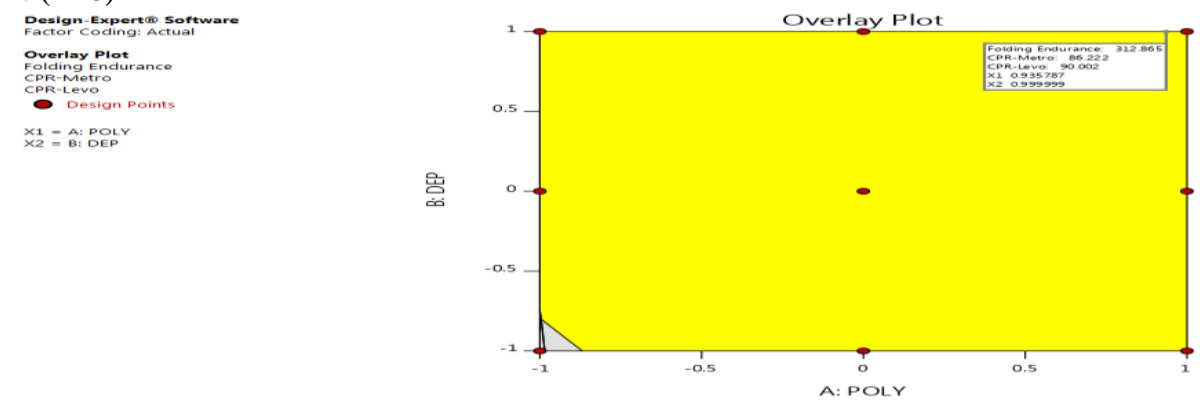

Fig. 5: Overlay Plot for Predicted Optimized Formulation of ML Chips (PLGA 85:15)

Lal et al ASIAN PACIFIC JOURNAL OF NURSING AND HEALTH SCIENCES, 2020; 3(2):25-37 
Table 12: Optimization of Metronidazole-Levofloxacin Chips (PLGA 85:15)

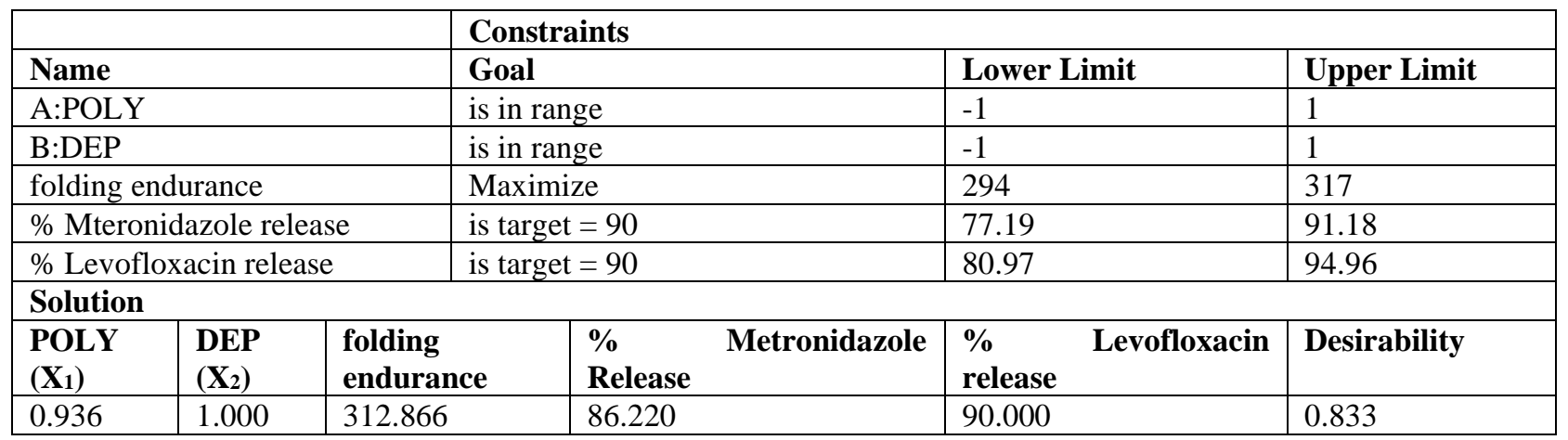

Formulation \& Evaluation of optimized sustained release chips

The optimized Metronidazole-Levofloxacin periodontal chip was prepared with the optimized amount of polymer PLGA and plasticizer diethyl phthalate suggested by the software and evaluated for all the parameter above mentioned in phrases 3.1 to 3.9. It was observed that all formulation showed the appropriate in-vitro release as proposed by the software. It was also observed that chips prepared using PLGA 85:15 (F1) showed good and controlled release of both drugs.

\section{Table 13: Development \& Evaluation of Optimized Formulation}

\begin{tabular}{|c|c|}
\hline Ingredients/Formulation & OPT PLGA 85:15(F1) \\
\hline Metronidazole $(\mathrm{mg})$ & 500 \\
\hline Levofloxacin (mg) & 500 \\
\hline poly(PLGA 85:15) (mg) & 1968 \\
\hline poly(PLGA 75:25) (mg) & - \\
\hline Diethyl phthalate $(\mathrm{ml})(40 \%$ of POLY) & 0.78 \\
\hline \multicolumn{2}{|l|}{ Evaluation } \\
\hline Weight $(\mathrm{mg})\left(0.3 \mathrm{~cm}^{2}\right.$ area chip $)$ & $13.2 \pm 0.17$ \\
\hline Thickness (mm) & 0.52 \\
\hline Folding endurance & $318 \pm 0.25$ \\
\hline Tensile strength $(\mathrm{Mp})$ & $0.341 \pm 0.045$ \\
\hline Surface pH & $6.52 \pm 0.04$ \\
\hline Swelling Index & $37.8 \pm 0.5$ \\
\hline Drug content Uniformity (Metro) & 90.51 \\
\hline Drug content Uniformity (Levo) & 93.45 \\
\hline In-vitro Drug release (\%) $\mathrm{Q}_{5 \text { days }}($ Metronidazole) & 88.17 \\
\hline In-vitro Drug release (\%) $\mathrm{Q}_{\text {5days }}($ Levofloxacin $)$ & 91.25 \\
\hline
\end{tabular}

Table 14(a-b) shows release profile ofMetronidazole\&Levofloxacin from chips containing PLGA 85:15 respectively.The prepared chips were evaluated for its physiochemical properties, kinetics and stability studies. Fig. 6 showscomparison of Percent Drug Release of Optimized formulations.

Table 14(a): Dissolution profile of Metronidazole from chips containing PLGA [85:15]

\begin{tabular}{|l|l|l|l|l|}
\hline Time in days & Avg. Abs. $(\mathrm{nm})$ & $\begin{array}{l}\text { Conc. of drug } \\
\text { released }(\mu \mathrm{g})\end{array}$ & $\begin{array}{l}\text { Cumulative release } \\
(\mu \mathrm{g})\end{array}$ & $\begin{array}{l}\% \text { Conc. of drug } \\
\text { released }\end{array}$ \\
\hline 0 & 0 & 0 & 0 & 0 \\
\hline 1 & 0.265 & 4183.3 & 4183.3 & 78.93 \\
\hline 2 & 0.041 & 450.0 & 4633.3 & 87.42 \\
\hline 3 & 0.022 & 133.3 & 4766.7 & 89.94 \\
\hline 4 & 0.016 & 33.3 & 4800.0 & 90.57 \\
\hline 5 & 0.015 & 16.7 & 4816.7 & 90.86 \\
\hline
\end{tabular}

Lal et al www.apinh.com 
Table 14(b): Dissolution profile of Levofloxacin from chips containing PLGA [85:15]

\begin{tabular}{|l|l|l|l|l|}
\hline Time in days & Avg. Abs. $(\mathrm{nm})$ & $\begin{array}{l}\text { Conc. of drug } \\
\text { released }(\mu \mathrm{g})\end{array}$ & $\begin{array}{l}\text { Cumulative release } \\
(\mu \mathrm{g})\end{array}$ & $\begin{array}{l}\text { \% Conc. of drug } \\
\text { released }\end{array}$ \\
\hline 0 & 0 & 0 & 0 & 0 \\
\hline 1 & 0.261 & 4333.3 & 4333.3 & 81.76 \\
\hline 2 & 0.038 & 421.1 & 4754.4 & 89.71 \\
\hline 3 & 0.020 & 105.3 & 4859.6 & 91.69 \\
\hline 4 & 0.018 & 70.2 & 4929.8 & 93.02 \\
\hline 5 & 0.016 & 35.1 & 4964.9 & 93.68 \\
\hline
\end{tabular}

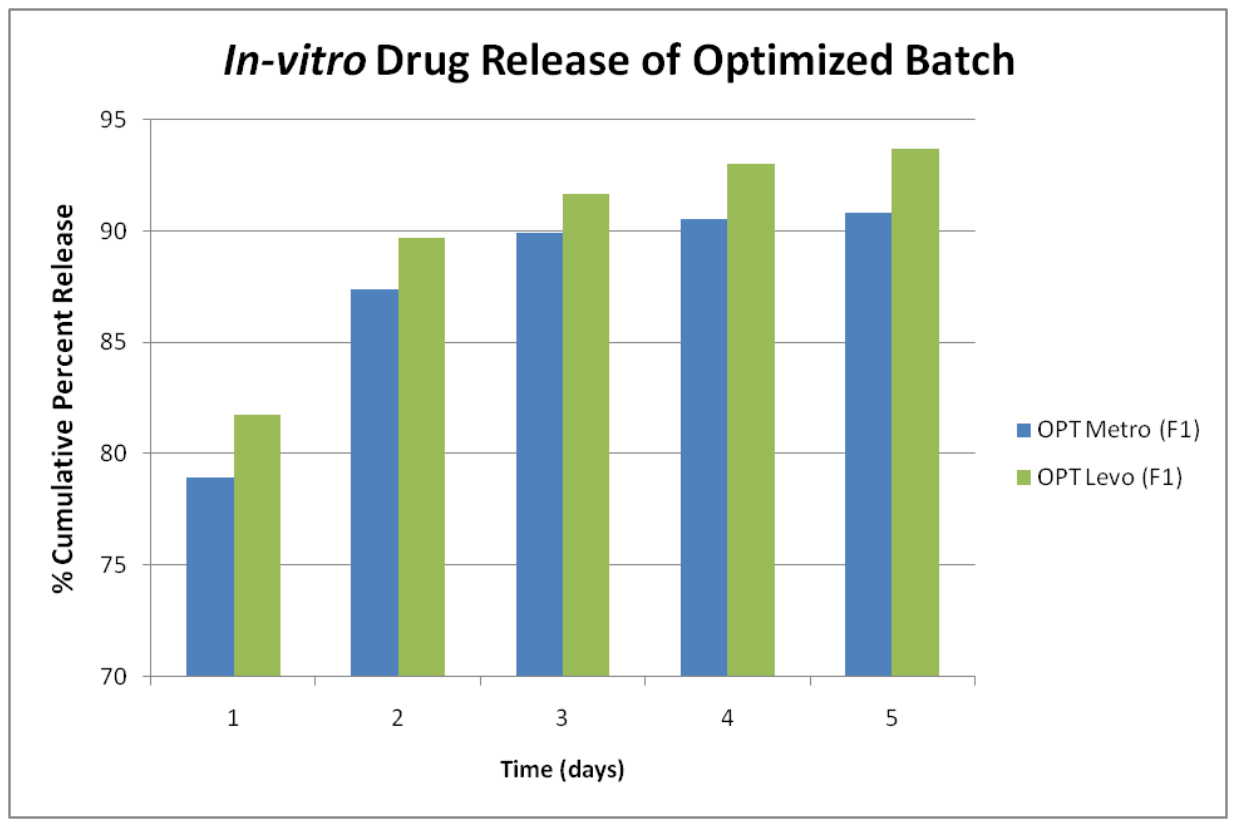

Fig. 6: Comparison of Percent Drug Release of Optimized formulations

\section{Release Kinetic Study [16-20]}

Several theories and kinetic models describe the dissolution of drug from immediate release and modified release dosage forms. There are several models to represent the drug release profiles where it is a function of time related to the amount of drug dissolved from the pharmaceutical dosage form.Drug dissolved from solid dosage forms has been described by kinetic models in which the dissolved amount of drug $(\mathrm{Q})$ is a function of the test time, $t$ or $\mathrm{Q}(\mathrm{t})$. Some analytical definitions of the $\mathrm{Q}(\mathrm{t})$ function are commonly used, such as zero order, first order, Higuchi, Hixson-Crowell,Korsmeyer-Peppas. These models are used to characterize drug dissolution/release profiles.

Model fitting was done to observe the release pattern of the drug(s) from the chips for all the optimized formulation. It was observed that all the formulation followed KorsmeyerPeppas model release kinetics as the $\mathrm{R}^{2}$ value is maximum and approaches to 1 for $\mathbf{F} 1$.

Table 15: Value of various parameters after Model fitting on Optimized formulations

\begin{tabular}{|l|l|l|l|l|l|l|l|l|l|l|}
\hline Parameter & \multicolumn{3}{|l|}{ Zero Order } & \multicolumn{3}{l|}{ first order } & \multicolumn{2}{l|}{$\begin{array}{l}\text { Korsmeyer- } \\
\text { Peppas }\end{array}$} & & \multicolumn{3}{|l|}{$\begin{array}{l}\text { Fixson-Crowell } \\
\text { F1 } \\
\text { (Metro) }\end{array}$} & $\begin{array}{l}\text { F1 } \\
\text { (Levo) }\end{array}$ & $\begin{array}{l}\text { F1 } \\
\text { (Metro) }\end{array}$ & $\begin{array}{l}\text { F1 } \\
\text { (Levo) }\end{array}$ & $\begin{array}{l}\text { F1 } \\
\text { (Metro) }\end{array}$ & $\begin{array}{l}\text { F1 } \\
\text { (Levo) }\end{array}$ & $\begin{array}{l}\text { F1 } \\
\text { (Metro) }\end{array}$ & $\begin{array}{l}\text { F1 } \\
\text { (Levo) }\end{array}$ & $\begin{array}{l}\text { F1 } \\
\text { (Metro) }\end{array}$ & $\begin{array}{l}\text { F1 } \\
\text { (Levo) }\end{array}$ \\
\hline $\mathrm{R}^{2}$ & $\mathbf{0 . 7 2 9}$ & $\mathbf{0 . 7 8 8}$ & $\mathbf{0 . 7 1 1}$ & $\mathbf{0 . 7 5 3}$ & $\mathbf{0 . 8 9 5}$ & $\mathbf{0 . 9 3 0}$ & $\mathbf{0 . 7 7 6}$ & $\mathbf{0 . 8 5 6}$ & $\mathbf{0 . 8 2 2}$ & $\mathbf{0 . 8 7 0}$ \\
\hline Slope & 0.113 & 0.113 & -0.008 & -0.009 & 0.088 & 0.084 & 96.530 & 91.261 & 1.902 & 1.892 \\
\hline Intercept & 79.441 & 81.827 & 1.680 & 1.664 & 1.784 & 1.803 & -11.073 & -12.08 & 71.922 & 74.433 \\
\hline
\end{tabular}

\section{In Vitro Antibacterial Activity}

In vitro antibacterial activity was performed on all formulations by putting the chip, $(10 \times 3 \mathrm{~mm})$ in broth tube seeded with oral bacteria, Pseudomonas spp. Bacteroides spp. After 48 hours of incubation at $37^{\circ} \mathrm{C}$, the chips were transferred onto freshly seeded broth 
tubes for an additional 48 hours for incubation. This procedure was repeated until bacterial growth was observed in the broth tube. Similarly control and Standard groups are also studies.

Though all the formulations show about than $90 \%$ release in 5 days, of which $\mathrm{F} 1$ showed maximum release with good in-vitro antibacterial activity also. It was prepared using $1968 \mathrm{mg}$ (i.e. 0.936 parts of $2000 \mathrm{mg}$ as suggested by software) of PLGA [85:15] and $0.78 \mathrm{ml}$ of Diethyl phthalate (i.e. $40 \% \mathrm{v} / \mathrm{w}$ of PLGA) by solvent casting method using acetic acid as solvent.

Table 16: Observation of bacterial growth in various formulations

\begin{tabular}{|c|c|c|c|c|c|c|c|c|c|c|c|c|c|c|}
\hline \multirow{2}{*}{$\begin{array}{l}\text { Formulation } \\
\text { Code }\end{array}$} & \multicolumn{7}{|c|}{ Pseudomonas spp. } & \multicolumn{7}{|c|}{ Bacteroides spp. } \\
\hline & $\begin{array}{l}24 \\
\mathrm{hr}\end{array}$ & $\begin{array}{l}48 \\
\mathrm{hr}\end{array}$ & $\begin{array}{l}72 \\
\mathrm{hr}\end{array}$ & $\begin{array}{l}96 \\
\mathrm{hr}\end{array}$ & $\begin{array}{l}120 \\
\mathrm{hr}\end{array}$ & $\begin{array}{l}148 \\
\mathrm{hr}\end{array}$ & $\begin{array}{l}172 \\
\mathrm{hr}\end{array}$ & $\begin{array}{l}24 \\
\mathrm{hr}\end{array}$ & $\begin{array}{l}48 \\
\mathrm{hr}\end{array}$ & $\begin{array}{l}72 \\
\mathrm{hr}\end{array}$ & $\begin{array}{l}96 \\
\mathrm{Hr}\end{array}$ & $\begin{array}{l}120 \\
\mathrm{hr}\end{array}$ & $\begin{array}{l}148 \\
\mathrm{hr}\end{array}$ & $\begin{array}{l}172 \\
\mathrm{hr}\end{array}$ \\
\hline $\mathrm{F} 1$ & - & - & - & - & - & + & + & - & - & - & - & - & - & + \\
\hline
\end{tabular}

\section{Stability Study}

The stability of the entire drug loaded polymer chip was studied at different temperatures using the reported procedure. The chips of size $(10 \times 3 \mathrm{~mm})$ were weighed in three sets (4 chip in each set). The chips films were wrapped individually in aluminum foil and also in butter paper and placed in Petri dishes. These containers were stored at room temperature $\left(27 \pm 2{ }^{\circ} \mathrm{C}\right)$, oven temperature $\left(40 \pm 2^{\circ} \mathrm{C}\right)$ and in a refrigerator $(5-8$ $\pm 2^{\circ} \mathrm{C}$ ) for a period of three months. All the polymeric chips were observed for any physical changes, such as color, appearance, flexibility, or tensile strength, and the drug content was estimated at an interval of one week. Furthermore, the amount of drug in the chip was estimated spectrophotometrically. Optimized formulation F-1 also showed very good stability profile.

Table 17: Stability results of optimized formulation F1

\begin{tabular}{|c|c|c|c|c|c|c|}
\hline \multirow[t]{2}{*}{ S. No. } & \multirow{2}{*}{\multicolumn{2}{|c|}{ Parameters }} & \multicolumn{4}{|c|}{$\begin{array}{l}\text { Storage Period (Days) } \\
\text { at } 40 \pm 2^{\circ} \mathrm{C} \text { temperature and } 75 \pm 5 \% \mathrm{RH}\end{array}$} \\
\hline & & & 7 & 14 & 21 & 28 \\
\hline 1 & \multirow{3}{*}{ 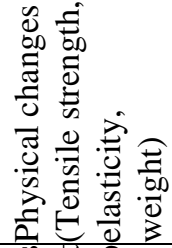 } & $\begin{array}{l}\text { Room Temp. } \\
\left.2^{\circ} \mathrm{C}\right)\end{array}$ & satisfactory & satisfactory & satisfactory & satisfactory \\
\hline 2 & & $\begin{array}{l}\text { Oven temp. }(40 \quad \pm \\
\left.2^{\circ} \mathrm{C}\right)\end{array}$ & satisfactory & satisfactory & satisfactory & $\begin{array}{l}\text { Slight elasticity } \\
\text { changes }\end{array}$ \\
\hline 3 & & $\begin{array}{l}\text { Refrigerator temp. }(5- \\
\left.8 \pm 2^{\circ} \mathrm{C}\right)\end{array}$ & satisfactory & satisfactory & satisfactory & satisfactory \\
\hline 4 & \multirow{3}{*}{ 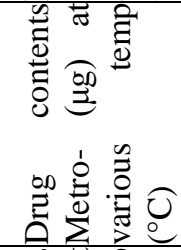 } & $\begin{array}{l}\text { Room Temp. } \quad(27 \pm \\
\left.2^{\circ} \mathrm{C}\right)\end{array}$ & 4986 & 4986 & 4982 & 4983 \\
\hline 5 & & $\begin{array}{l}\text { Oven temp. }\left(\begin{array}{lll}40 & \pm \\
\left.2^{\circ} \mathrm{C}\right)\end{array}\right. \\
\end{array}$ & 4991 & 4992 & 4988 & 4989 \\
\hline 6 & & $\begin{array}{l}\text { Refrigerator temp. }(5- \\
\left.8 \pm 2^{\circ} \mathrm{C}\right)\end{array}$ & 4976 & 4977 & 4977 & 4970 \\
\hline 7 & \multirow{3}{*}{ 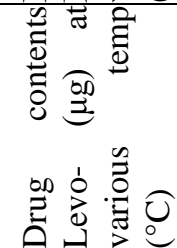 } & $\begin{array}{lll}\text { Room } & \text { Temp. } & (27 \pm \\
\left.2^{\circ} \mathrm{C}\right) & & \\
\end{array}$ & 5013 & 5013 & 5012 & 5013 \\
\hline 8 & & $\begin{array}{l}\begin{array}{l}\text { Oven temp. }(40 \quad \pm \\
\left.2^{\circ} \mathrm{C}\right)\end{array} \\
\end{array}$ & 5025 & 5020 & 5008 & 5006 \\
\hline 9 & & $\begin{array}{l}\text { Refrigerator temp. }(5- \\
\left.8 \pm 2^{\circ} \mathrm{C}\right)\end{array}$ & 4998 & 4998 & 4996 & 4997 \\
\hline
\end{tabular}

\section{Conclusion}

The present study succeeded in the fabrication ofbiodegradable, Metronidazole-Levofloxacin sustained release chips of poly(d,l-lactide-co-glycolide) (DL-PLGA 85:15)by solvent casting method.Processing factors such asplymerDL-PLGA $85: 15$, plasticizer and diethyl phthalate concentration have significantly affectedthe physical characteristics of film and were found withinacceptable range. PLGAconcentration has negatively affecteddrug release and positively affected T90 due to alteredmatrix density. On the contrary, plasticizer concentrationhas positively affected the rate of drug release and negativelyaffected T90 of both drugs attributed to

Lal et al

ASIAN PACIFIC JOURNAL OF NURSING AND HEALTH SCIENCES, 2020; 3(2):25-37 
increasedmembrane permeability. The release of drugs frombiodegradablechips showed sustained release for 7 days.

Design-Expert® (11.0.4) software was used to study the effect of polymer \& plasticizer on release of drugs as well as for designing \& optimization of batches;drawing of response surface plots \& contour plots; and selection of optimum formulations by desirability plots. Forvarious response variables,polynomial mathematical models were generated usingmultiple regression analysis, and found to be statistically significant $(P<0.05)$. Optimized formulations were further used for preparing optimized biodegradable, Metronidazole-Levofloxacin sustained release chip.The use of combinationof drugs has proven to surpass the potential over singledrug film and placebo film during antibacterial study andclinical study. The local delivery of both drugs in asustained release formula enhances the therapeutic effectof SRP as demonstrated by the measured clinical parameters.Conclusively, such cheap, less resourcerequiringfilm devices have great market potential to administermedicament locally into the periodontal pockets for themanagement of periodontitis.

\section{References}

1. S.P.Vyas, V.Sihorkar and V.Mishra, Controlled and targeted drug strategies towards intraperiodontal pocket diseases, journal of clinical pharmacy and therapeutics.2000;25: 21-42.

2. Nilu Jain, Gaurav K. Jain, ShamamaJaved, ZeenatIqbal, SushamaTalegaonkar, Farhan J. Ahmad and Roop K. Khar, Recent approach for the treatment of periodontitics, Drug Discovery Today. 2008;13 (21):932-943.

3. Amal Hassan E. Kamel, Lubna Y. Ashri, and Ibrahim A. Alsarra, Micromatricial Metronidazole Benzoate Film as a Local Mucoadhesive Delivery System for Treatment of Periodontal Diseases, AAPS PharmSciTech.2007;8(3):E1-E11.

4. Perioli L, Ambrogi V, Rubini D, Giovagnoli S, Ricci M, Blasi P, et al. Novel mucoadhesivebuccal formulation containing metronidazole for the treatment of periodontal disease. J Control Release. 2004;95(3):521-33.

5. Ogrendik M. Levofloxacin treatment in patients with rheumatoid arthritis receiving methotrexate. South Med J. 2007;100(2):135-9.

6. Danser MM, Timmerman MF, van Winkelhoff AJ, van der Velden U. The effect of periodontal treatment on periodontal bacteria on the oral mucous membranes. Journal of Periodontology, 1996;67:478485.

7. K. Schwach-Abdellaouia, N. Vivien-Castionib, R. Gurnya, Review article Local delivery of antimicrobial agents for the treatment of periodontal diseases, European Journal of Pharmaceutics and Biopharmaceutics. 2000;50 : 83-99.

8. Jain NK. Controlled and novel drug delivery 1st edition, New Delhi CBS Publication. 1997:130-147.

9. Rahman S, Ahuja. A, Ali. J, Khar RK. Site Specific delivery systems for the treatment of periodontitis. Indian J Pharm Sci. 2003;65(2): 106-112.

10. Robinson JR, Vincent HL, Lee. Controlled drug delivery, Fundamentals and applications. 2nd ed: Marcel Dekker. (1987) 159-163.

11. S. Umadevi, R. Beetha, Nithyapriya, Sasidharan. Formulation and evaluation of Ciprofloxacin dental films for periodontitis. J Chem\& Pharm Res. 2012; 4(6): 2964- 71.

12. V C Vineetha, M MManju. Development and evaluation of dental films containing an antibacterial agent for the treatment of periodontitis. International Journal of Pharmacy and Pharmaceutical Sciences. 2015; 7(3): 1 .

13. C N Sreeja, K R Anoop. Local antimicrobial delivery of satranidazole loaded cross linked periodontal chips using bio degradable polymers. International Journal of Pharmacy and Pharmaceutical Sciences. 2013; 5(3):8.

14. Costa, P.; Manuel, J.; Sousa, L. Modeling and comparison of dissolution profiles: A review. Eur. J. Pharm. Sc. 2001;13:123-133.

15. Korsmeyer R.W., Gurny R., Doelker E., Buri P. and Peppas N.A. Mechanisms of solute release from porous hydrophilic polymers. International Journal of Pharmaceutics. 1983;15:25-35.

16. Hixson AW, Crowell J.H. Dependence of Reaction Velocity upon surface and Agitation. Industrial \& Engineering Chemistry. 1931;23:923-931.

17. Lachman L, Lieberman HA, Kanig JL. The Theory \& Practice of Industrial Pharmacy. Varghese Publishing House. $3^{\text {rd }}$ Edition, Reprint 1991;760-803.

18. Yuksel N, Kanik AE, Baykara T. Comparison of in vitro dissolution profiles by ANOVA-based, modeldependent and independent methods. Int. J. Pharm. 2000;209:57-67.

19. "Metronidazole". In: Martindale: The complete Drug Reference. Pharmaceutical Press. $36^{\text {th }}$ Edition 2009:837-41.

20. "Levofloxacin". In: Martindale: The complete Drug Reference. Pharmaceutical Press. $36^{\text {th }}$ Edition 2009:292-93.

\section{Source of Support: Nil Conflict of Interest: Nil}

